\title{
News from our place: AICCAS and MACS Australia-wide:
}

\author{
This column will be available in every issue of Children Australia for 1993. All Aboriginal \& Islander child care \\ agencies and Multifunctional Children's Services are invited to let us know about issues, needs and problems in \\ your area; things which are ahppening; notable achievements; and ideas and dreams for the future.
}

\section{Yera Child Care Centre, Batchelor}

\section{Lisa Paddison - Director}

Yera Child Care Centre is the MACS attached to Batchelor College in the Northern Territory, $100 \mathrm{~K}$ south of Darwin. Batchelor College is a multi-purpose institute of Tertiary Education for Aboriginal and Islander people, offering accredited courses in such things as Teacher Education, Health, Broadcasting and Joumalism, Office Administration, Community Management, Early Childhood Education, Sport and Recreation, Language and Linguistics and Land, Parks and Wildlife Management.

The Child Care Centre offers services for the children of students attending the college. Our services include a 25 place long day centre, a 15 place Family Day Care scheme and an after-school Enrichment Program for primary school aged children.

1993 will be a year of change for Yera. We are getting ready to move from a temporary facility into a new, purpose-built 50 place centre. Although this new centre will be licensed for 50 children under the age of 6 , we will not be able to increase our numbers due to no increases in funding (operational subsidies etc) from the Commonwealth. We hope that this situation will change in the future, as the College continues to grow and to offer more and more courses to more and more students, and there is an ever-growing demand for child care.

A notable achievement in our centre in the last month has been that we have been lucky enough to be able to employ a new qualified child care worker, Dee Uibo, who is a graduate of Batchelor College with a Diploma in Teaching. Dee is an Aboriginal woman who was born and raised in Numbulwar in the Gulf of Carpentaria. She has lived and worked in many Top End communities, and she speaks many Aboriginal languages, including Yolgnu Matha and Kriol. This is a great asset to our centre, as our children come from bush communities all over the Northem Territory and Top End of Western Australia and Queensland, and many of them do not speak English. Dee is also a great resource for our other staff, both Aboriginal and non-Aboriginal, and her input into the centre will be invaluable.

There are many dreams and ideas for the future at Yera. Some are simple ones, like wishing, hoping and waiting for the funding for a bus for the service. We would especially like to be able to extend our Enrichment Program, both in the hours we can offer the program, (presently 20 hours per week), and to reach a greater number of children, especially post-primary children aged 12-16 years. There is very little for kids this age to do in Batchelor, and they mostly just hang around. There are no jobs, no sport, no recreation, nothing. It would be great if we could offer something for these kids, who often seem to get left out of the equation. Even if it was just a place to play pool.

Well, that's all from the Top End. I look forward to seeing the national journal, Children Australia, especially reading thoughts from colleagues in other MACS and AICCAS.

\section{Coolabaroo Neighbourhood Centre}

\section{Joanne Della Bona}

Coolabaroo's child intake is fifty-seven. Of those fiftyseven, $80 \%$ are Aboriginal. Some of these children are referrals from Department of Community Development, which is a concern as some of these children have certain problems. We are funded for staff according to the staffchild ration in the regulations. Due to the nature of funding it is impossible to provide 1 on 1 for those children, who have 'difficulties/problems'. Therefore we feel we are unable to provide for these Aboriginal children as adequately as we would like.

Coolabaroo has received funding from ATSIC and lotteries, and did our own fundraising for the development of a playground - which should be completed by June. Our children will then have equipment such as slides, flying fox and a fort to play in. Prior to this development Coolabaroo has had 'near to none' outdoor climbing equipment. We take in 15 babies, 15 toddlers, $153-4 \mathrm{~s}$ and 12 pre-schoolers and 30 out-of-school hours care children.

Coolabaroo set up a program in 1992/93 called 'Yarning Program'. The program involved many older members of the Aboriginal community coming to Coolabaroo to share their knowledge with the children. The children were encouraged to talk and leam the Noongar language. The interaction between young and old ranges from talking, reading, telling stories. This program was a finalist in the Project 92 Awards, run by Children's Advisory Council.

For the future, we have had plans for an extension, which will incorporated offices for the Health Department of WA, the Aboriginal Legal Service and an Aboriginal Medical Service as well as an increase in space for children's rooms. Up to this time, we have been unsuccessful in obtaining the funds of $\$ 300,000$ needed for this to occur.

Coolabaroo will still strive to obtain its dream for the future. 


\section{ABORIGINAL \& ISLANDER CHILD CARE AGENCIES}

\section{NEW SOUTH WALES}

Betsy Coe

Aboriginal Children's Services

130 Redfem Street

REDFERN NSW 2016

Ph. (02) 6999835

Joe Perry

Hunter Aboriginal Children's Services

PO Box 282

HAMILTON NSW 2303

Ph. (049) 612423

NSW Branches:

PO Box 796

ST MARYS NSW 2760

PO Box 50

WAGGA NSW 2650

PO Box 610

COWRA NSW 2794

\section{NORTHERN TERRITORY}

Merle Simpson

Central Australian Aboriginal Child Care Agency

PO Box 2438

ALICE SPRINGS NT 5750

$\mathrm{Ph}(089) 527140$

Barbara Cummins

Karu Aboriginal Child Care Agency

PO Box 40639

CASUARINA NT 0811

Ph. (089) 227171

\section{TASMANIA}

Lisa Coulson

Tasmanian Aboriginal Child Care

89 Lower Lindsay Street

LAUNCESTON TAS 7250

Ph. (003) 316671

\section{WESTERN AUSTRALIA}

Lorraine Whitby

West Australian Aboriginal Child Care Committee

21 Pinewood Place

BEECHBORO WA 6063

Ph. (09) 3775082

Irene Stanton

Yorgonop Aboriginal Child Care Corporation

124 Parry Street

EAST PERTH WA 6000

Ph. (09) 2279022

\section{QUEENSLAND}

Robin Moylan

Yuddika Aboriginal \& Islander Child Care Agency

91 Draper Street

CAIRNS QLD 4970

Ph. (070) 511388

Caroline Munns

Mt Isa Aboriginal Child Care Agency

PO Box 1324

MT ISA QLD 4825

Ph. (077) 439626

Racheal Cummins

Townsville Aboriginal \& Islanders Child Care Agency PO Box 312

HERMIT PARK QLD 4812

Ph. (077) 726466

Norm Brown

Brisbane Aboriginal \& Islanders Child Care Agency 751 Stanley St

WOOLLOONGABBA QLD 4120

Ph. (07) 3915466

Linda Black

Rockhampton Aboriginal Child Care Agency

PO Box 158

ROCKHAMPTON QLD 4700

Jacky Cannon

Barambah Aboriginal Islander Child Care Agency

PO Box 168

MURGON QLD 4605

Ph. (071) 212108

\section{SOUTH AUSTRALIA}

Brian Butler

South Australian Aboriginal Child Care Agency

29 North Terrace

ADELAIDE SA 5000

Ph. (08) 2121112

\section{VICTORIA}

Darren Lovett

Victorian Aboriginal Child Care Agency

4 Brunswick Place

FITZROY VIC 3065

Ph. (03) 4197899 